DOI: https://doi.org/10.15688/jvolsu5.2016.4.19

UDC 343.139

LBC 67.311

\title{
SOME ASPECTS OF COLLECTING EVIDENCE IN THE COURT OF APPEAL
}

\author{
Oksana V. Shabunina \\ Volgograd Regional Court, Volgograd, Russian Federation
}

\begin{abstract}
Introduction. The issues connected with the collection of evidence during hearing of a criminal trial in the court of appeal are burning and given a great deal of consideration both in the academic community and by law enforcement officials. Currently the court of appeal possesses the same range of ways for collection of evidence as the court of the first instance, but considering some peculiarities as provided for by chapter 45.1 of the Russian Federation Code of Criminal Procedure. In this respect the author of the work sets a purpose to study and analyze some of the aspects of collection of evidence in the court of appeal. Methods. Methodological foundation of this research consists of a system of procedures of scientific knowledge. The centerpiece includes methods of consistency, analysis, synthesis and a comparative-legal method. Results. The position of the author justified in the work is based on the legislation in power and interpretations of the Plenum of the Supreme Court of the Russian Federation. In accordance with the analysis of regulations given in chapter 45.1 of the Russian Federation Code of Criminal Procedure, peculiarities of evidence collection at the stage of appeal proceedings are considered. It is pointed out that implementation of capabilities for collecting evidence provided by the law for parties depends on the discretion of the court. Conclusions. As a result of the research the author makes suggestion to codify a detailed procedure of hearing a trial carried out by the court of appeal which would allow to improve the institution of collection of evidence at the stage of appeal proceedings and would help avoid judicial errors during hearing of criminal trials in court of the first instance.
\end{abstract}

Key words: collection and investigation of evidence, averment, court of appeal, discretion of the court, legal proceedings.

УДК 343.139

ББК 67.311

\section{НЕКОТОРЫЕ АСПЕКТЫ СОБИРАНИЯ ДОКАЗАТЕЛЬСТВ В СУДЕ АПЕЛЛЯЦИОННОЙ ИНСТАНЦИИ}

\author{
Оксана Владимировна Шабунина \\ Волгоградский областной суд, г. Волгоград, Российская Федерация
}

Введение: проблемы, связанные с собиранием доказательств при рассмотрении уголовных дел в суде апелляционной инстанции, являются актуальными и активно обсуждаемыми как в научном сообществе, так и правоприменителями. В настоящее время суд апелляционной инстанции располагает тем же арсеналом способов собирания доказательств, что и суд первой инстанции, но с учетом ряда особенностей, предусмотренных главой 45.1 УПК РФ, в связи с чем автором в работе поставлена цель исследования и анализа некоторых аспектов собирания доказательств в суде апелляционной инстанции. Методы: методологическую основу данного исследования составляет совокупность методов научного познания, среди которых основное место зани6 мают методы системности, анализа, синтеза и сравнительно-правовой. Результаты: обоснованная в работе 궁 авторская позиция опирается на действующее законодательство и разьяснения Пленума Верховного суда РФ. Н На основании анализа норм, содержащихся в главе 45.1 УПК РФ, рассматриваются особенности собирания доказательств на стадии апелляционного производства. Делается акцент на том, что реализация предоставлен⿷匚 ных законом для сторон возможностей по собиранию доказательств с учетом действующих положений закона зависит от усмотрения суда. Выводы: в результате проведенного исследования автор предлагает законодательно закрепить детальную процедуру рассмотрения дела судом апелляционной инстанции, что позволило бы усовершенствовать институт собирания доказательств на стадии апелляционного производства. 
Ключевые слова: собирание и исследование доказательств, доказывание, суд апелляционной инстанции, судебное усмотрение, производство уголовного дела.

\section{Введение}

В процессе рассмотрения уголовного дела судом апелляционной инстанции одно из наиболее важных мест занимает вопрос о доказывании при производстве по уголовному делу. Процедуру классической апелляции от классической кассации отличает пересмотр судебного решения как с точки зрения его юридической стороны, так и с точки зрения фактических обстоятельств дела. Процесс доказывания при производстве по уголовному делу в суде апелляционной инстанции связан с собиранием, проверкой и оценкой доказательств. Способы практического собирания доказательств исчерпывающе указаны в ст. 86 УПК РФ и связаны с поисковой, познавательной деятельностью (получение предметов и документов, истребование справок, характеристик).

\section{Особенности собирания доказательств в суде апелляционной инстанции}

Суд апелляционной инстанции в процессе собирания доказательств проводит следственные и иные процессуальные действия так же, как и суд первой инстанции, но с учетом ряда особенностей [5].

Во-первых, собирание доказательств в суде апелляционной инстанции согласно положениям ст. 389.9 УПК РФ проводится с точки зрения предмета судебного разбирательства в апелляционном порядке, который определяет законность, обоснованность, справедливость приговора, а также законность и обоснованность иного решения суда первой инстанции. В первую очередь в апелляции проверяются те доказательства, на которые ссылаются стороны в своих апелляционных жалобах и представлениях. Лица, которым предоставлено право обжалования приговоров и иных решений суда первой инстанции, сами решают, обращаться им с апелляционной жалобой или нет.

Вместе с тем из данного правила имеется исключение: прокурор, представляющий в судебном разбирательстве публичные интересы, должен обжаловать каждое судебное решение, если придет к убеждению, что при вынесении такого решения судом был неправильно применен уголовный закон или допущены нарушения уголовно-процессуального закона [6, с. 9].

Кроме того, в процессуальном законе содержатся прямые ограничения на собирание и исследование доказательств в суде апелляционной инстанции.

Положение процессуального закона о собирании доказательств в апелляции с точки зрения предмета судебного разбирательства упрощает процедуру собирания доказательств, что подтверждается положениями, закрепленными в ч. 3 ст. 389.13 УПК РФ, о том, что в ходе судебного следствия после доклада председательствующего или судьи и выступления сторон по существу принесенных жалоб или представлений суд переходит к проверке доказательств.

\section{Исследование доказательств в суде апелляционной инстанции}

В главе 37 УПК РФ, регламентирующей судебное следствие в суде первой инстанции, употребляется термин «исследование доказательств», то есть суд непосредственно исследует доказательства, а при рассмотрении дела в апелляционном порядке проверяет доказательства. Вместе с тем в суде апелляционной инстанции стороны также вправе ходатайствовать об исследовании доказательств, на что указывает ч. 6 ст. 389.13 УПК РФ.

Анализ положений уголовно-процессуального закона приводит к выводу, что термин «исследование» применяется в более широком значении, чем «проверка». Исследование включает как процесс получения информации (допрос свидетеля), так и проверку полученных сведений (ст. 240 УПК РФ). А под проверкой доказательств ст. 87 УПК РФ подразумевает сопоставление их с другими доказательствами, имеющимися в уголовном деле.

В качестве второй особенности собирания доказательств в суде апелляционной инстанции можно отметить положения ч. 5 ст. 389.13 УПК РФ о праве суда допросить 
свидетелей, допрошенных в суде первой инстанции, в случае, если суд признает их вызов необходимым, то есть по судебному усмотрению.

С учетом данной позиции законодателя ряд авторов высказывают мнение о том, что суд апелляционной инстанции не обязан допрашивать свидетелей и в том случае, если их показания оспариваются одной из сторон, например, как ложные или противоречивые [1, c. 63]. Однако основной целью собирания доказательств в апелляции является возможность установить факты нарушения закона при производстве по уголовному делу на стадии предварительного расследования или в суде первой инстанции. При таких обстоятельствах подобное дискреционное усмотрение суда апелляционной инстанции нивелирует права заинтересованных лиц к апелляционной судебной защите и выхолащивает назначение эффективного и познавательного по сути процессуального института, на что уже обращалось внимание ученых [4, с. 44].

\section{Возможность представления новых доказательств \\ в суде апелляционной инстанции}

Третьей особенностью собирания доказательств на стадии апелляционного производства является возможность исследования новых доказательств, не исследованных судом первой инстанции, по правилам, установленным в ч. 1 и 2 ст. 271 УПК РФ.

В связи с этим не исключено, что профессиональные участники судебного разбирательства, зная об определенном резерве в отстаивании своей позиции, не будут концентрировать все имеющиеся доказательства в суде первой инстанции и проявлять должную активность, что естественно для состязательного процесса [2, с. 23].

Во избежание возможных злоупотреблений правом и с целью побуждения сторон к активному собиранию доказательств в суде первой инстанции в ст. 389.13 УПК РФ Федеральным законом от 23 июля 2013 г. № 217Ф3 была введена ч. 6.1, которая предусматривает возможность принятия судом новых доказательств при наличии двух условий: вопервых, лицо, заявившее ходатайство об их ис- следовании, во-вторых, суд должен признать эти причины уважительными.

Изменения, внесенные уже упомянутым Федеральным законом № 217-Ф3 в ч. 6 ст. 389.13 УПК РФ, еще более ограничили стороны в познавательных средствах обоснования своих позиций в апелляционном суде.

Законодатель предоставляет сторонам возможность в подтверждение или опровержение доводов, приведенных в апелляционных жалобе, представлении, представить в суд дополнительные материалы. Исходя из системного толкования положений ст. 286 УПК РФ и главы 45.1 УПК РФ суд апелляционной инстанции и по собственной инициативе вправе истребовать дополнительные материалы, которые могут быть исследованы и приобщены к материалам уголовного дела.

Понятие дополнительных материалов процессуальный закон не раскрывает. Законодатель употребляет именно термин «материалы», а не «документы», следовательно, в качестве таковых, как справедливо отмечает А.А. Васяев, могут быть представлены не только письменные документы, но и различные предметы, вещи, то есть все, что охватывается более широким понятием «материалы» [3, с. 33].

Однако в Постановлении Пленума Верховного суда РФ речь ведется исключительно о документах - справках, характеристиках, иных документах от различных организаций и органов [5].

Закрепление в ст. 5 УПК РФ понятия «дополнительные материалы», используемого в главе 45.1 УПК РФ, способствовало бы единообразному подходу относительно того, что может быть представлено в качестве дополнительных материалов.

\section{Выводы}

Внесение в главу 45.1 УПК РФ изменений, определяющих процедуру рассмотрения дела судом апелляционной инстанции, явилось бы шагом к совершенствованию данного процессуального института. Закрепление традиционного судебного следствия в апелляционном производстве, установление обязанности суда непосредственно исследовать все доказательства, наделение сторон правом предоставлять 
дополнительные доказательства в суд апелляционной инстанции - те меры, которые вернут апелляции ее основной смысл.

\section{СПИСОК ЛИТЕРАТУРЫ}

1. Аверкин, А. Проверка и исследование доказательств в суде апелляционной инстанции / А. Аверкин, А. Кудрявцева, В. Смирнов // Уголовное право. - 2012. - № 6. - С. 57-65.

2. Аширбекова, М. Т. Новые доказательства в суде апелляционной инстанции / М. Т. Аширбекова // Российская юстиция. - 2013. - № 5. - С. 22-24.

3. Васяев, А. А. Исследование доказательств в ходе судебного следствия в суде апелляционной инстанции / А. А. Васяев // Адвокат. - 2011 . - № 6. C. $29-36$.

4. Ковтун, Н. Н. Апелляция год спустя: peaлии и прогнозы / Н. Н. Ковтун // Уголовный процесс. - 2014. - № 2. - С. 38-45.

5. Постановление Пленума Верховного суда РФ «О применении норм Уголовно-процессуального кодекса Российской Федерации, регулирующих производство в суде апелляционной инстанции» от 27 нояб. 2012 г. № 26. - Доступ из справ.правовой системы «КонсультантПлюс».

6. Халиулин, А. Г. Участие прокурора в рассмотрении уголовных дел в суде апелляционной и кассационной инстанций / А. Г. Халиулин, А. Н. Разинкина, Н. Ю. Решетова. - М. : Академия Генеральной прокуратуры РФ, 2013. - 160 с.

\section{REFERENCES}

1. Averkin A. Proverka i issledovaniye dokazatelstv v sude apellyatsionnoy instansii [Verification and investigation of evidence in the court of appeal]. Ugolovnoye pravo, 2012, no. 6, pp. 57-65.

2. Ashirbekova M.T. Novyye dokazatelstva v sude apellyatsionnoy instansii [New evidence in the court of appeal]. Rossiyskaya yustitsiya, 2013, no. 5, pp. 22-24.

3. Vasyaev A.A. Issledovaniye dokazatelstv v khode sudebnogo sledstviya $\mathrm{v}$ sude apellyatsionnoy instansii [Investigation of evidence in the course of judicial proceedings in the court of appeal]. Advokat, 2011, no. 6, pp. 29-36.

4. Kovtun N.N. Appellyatsiya god spustya: realii i prognozy [Appeal a year later: reality and forecasts]. Ugolovnyy protsess, 2014, no. 2, pp. 38-45.

5. Postanovlenie Plenuma Verkhovnogo Suda RF "O primenenii norm ugolovno-protsessualnogo kodeksa Rossiyskoy Federatsii" ot 27 noyabrya 2012 No 26 [Resolution of Plenum of the Supreme Court of the Russian Federation "On application of rules of the Russian Federation Code of Criminal Procedure which regulate proceedings in the court of appeal" of November 27, 2012 no. 26]. Access from reference legal system "KonsultantPlyus".

6. Khaliulin A.G. Uchastie prokurora $v$ rassmotrenii ugolovnykh del $v$ sude apellyatsionnoy i kassatsionnoy instansii [Participation of prosecutor in criminal trial in the court of appeal and court of cassation: education guidance]. Moscow, Akademiya Generalnoy prokuratury RF Publ., 2013. 160 p.

\section{Information About the Author}

Oksana V. Shabunina, Judge of Volgograd Regional Court, Prosp. Lenina, 8, 400066 Volgograd, Russian Federation, oksana.shabunina@mail.ru.

\section{Информация об авторе}

Оксана Владимировна Шабунина, судья Волгоградского областного суда, просп. Ленина, 8, 400066 г. Волгоград, Российская Федерация, oksana.shabunina@mail.ru. 